This Section of Epidemiology and Psychiatric Sciences appears in each issue of the Journal and is dedicated to all forms of creative production born of an intimate and individual urge, often secretive, unbound from the conventional art system rules. Through short descriptions of the Outsider art work of prominent artists and new protagonists often hosted in community mental health services, this section intends to investigate the latest developments of the contemporary art scene, where the distances between the edge and the centre are becoming more and more vague.

Carole Tansella, Section Editor

\title{
Jungle Phillips' total art
}

\section{Colin Rhodes*}

University of Sydney, NSW 2006, Australia

Received 17 June 2014; Accepted 26 June 2014; First Published online 4 September 2014

Key words: Art, painting, environments, trauma, Australia.
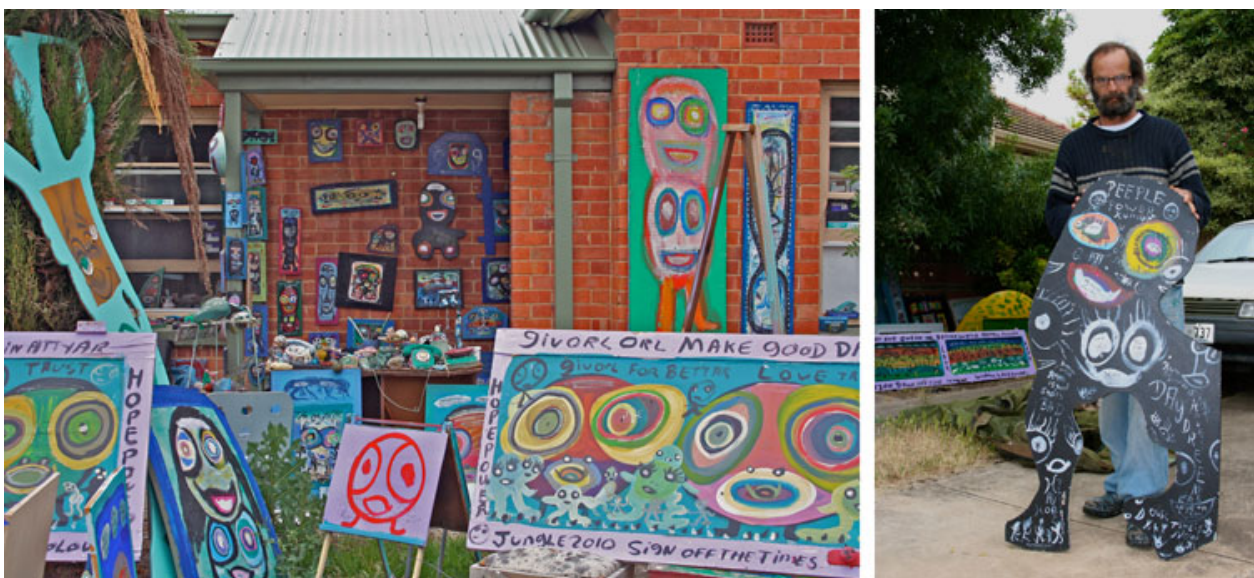

Jungle Phillips with 'Peeple Power', November 2010 (photograph Colin Rhodes). View of the front yard, 'Jungle's Legendary Art Home Studio', Adelaide, South Australia, November 2010 (photograph Colin Rhodes). Full colour version available as online Supplementary material http://dx.doi.org/10.1017/S2045796014000481

Peter 'Jungle' Phillips is a prolific painter who has transformed his house and yard into a teeming public art environment that he calls 'Jungle's Legendary Art Home Studio'. He has unlikely artistic beginnings. Born 2 months premature in Tasmania in 1956 and raised from the age of 5 by his father and grandmother after his parents divorced; his childhood environment

* Address for correspondence: Professor Colin Rhodes, Professor of Art History and Theory, Sydney College of the Arts, University of Sydney, Locked Bag 15, Rozelle NSW 2039, Australia.

(E-mail: colin.rhodes@sydney.edu.au) was violent and financially straightened. Lack of money led him to be creative, though, and he would fashion toys, bikes and go-carts from found objects and trash, although his art education did not continue past high school. He joined his brothers in Melbourne as a young man, where they were members of a motorcycle gang and where he acquired the 'Jungle' tag (it is 'bikie' slang for 'scatterbrain').

Jungle's art is in no small part a product of trauma and abuse, surfacing as a serious practice after he witnessed at close quarters his brother's suicide by gun in 1978. Someone advised him to work through the 
experience by making drawings, which unlocked the positive, creative urge. In the early 1990s, in an effort to escape the spiral of a hard lifestyle marked by drug and alcohol dependency and violence Jungle moved to Adelaide, South Australia, where he still lives today. There, in 1992, he began painting in earnest with the support of artist Tony Waite.

Jungle experienced a kind of epiphany in 1999, after he was the victim of a hit-and-run accident. At this point art making gained absolutely centrality in his life as a vehicle for revealing an intense visionary reality and for testifying his belief in the power of love and hope. 'I became a prolific artist,' he says, 'producing 1000 paintings a year' (Rhodes 2009). It is not so much the number of works that is important, though, as the expressionist collapsing together of art and life that Jungle's practice represents. There is a striking physicality to his paintings and 'cutups' (the name he gives to works made from found pieces of board), which contributes to the quality of vision-made-flesh that characterises his images. Works are quite literally extensions of himself both psychologically and existentially, full of hope, love, peace and the promise of salvation. 'I love to paint,' he says, 'and become the picture. I lose myself often when painting, which is all the time' (Rhodes 2009).

Everything is a possible surface for painting, from discarded doors and odd bits of wood, to household items and toys. Things are animated and transformed by the painted hallucinatory life forces that Jungle elicits from them. Here are spirits and daemons that he sees in the objects and all around him. The intensity of Jungle's perception is returned in the piercing gaze of his figures, which range from steady to almost hysterical. He intuitively employs hieratic perspective. The main figures are often visionary portraits of family members and friends, both living and dead. Smaller personages are presences both good and maleficent that jockey for attention. Out of this maelstrom of activity some simple, but profound truths are established: the connectedness of all things 'I believe that we are part of the land,' he says; the latent transformative power of adversity - 'I firmly believe that good comes out of bad'; and the necessity of positive thought and action, which is captured in the statements and slogans commonly added to works. Sometimes philosophical, sometimes reproducing stock Australian phrases, and often exhortational, the texts share Jungle's idiosyncratic spelling: 'stand torl' (stand tall); 'kummin atiyar hav hope day dreemers' (coming at you, have hope daydreamers); 'troo hart power' (true heart power); 'such is life'; 'fare goe mate' (fair go, mate).

Jungle's house is one big studio museum, covered inside and outside with his paintings, cut-ups and found objects (Pye 2006). The yard environment at the side of a busy inner-city highway is in a state of constant dynamic flux, from the 'gallery tree' to little dioramas of household junk. Everything, including his clothes and car, is always painted with a characteristic stock of people, spirits, Volkswagen Kombi vans and so on. Visitations are important to him; visitors not only animate the works through the experience of looking, but also provide opportunity for Jungle to expound on his philosophy of creativity and life. The richer is public interest, the richer the yard environment. In this way its content periodically wanes and waxes.

\section{Acknowledgements}

None.

\section{Financial Support}

This research received no specific grant from any funding agency, commercial or not-for-profit sectors.

\section{Conflict of Interest}

None.

\section{Supplementary materials and methods}

The Supplementary material referred to in this article can be found at http://dx.doi.org/10.1017/S2045796014000481.

\section{References}

Pye G (2006). 'Hopeland' Jungle Phillips. Accessed 16 June 2014 from http://www.vitaminarchive.com/hopeland/.

Rhodes C (2009). The Art of 'Jungle' Phillips, Exhibition Catalogue. Artereal Gallery: Sydney.

\section{About the author}

Colin Rhodes, Ph.D., is Professor and Dean at the University of Sydney, Director of the Self-Taught and Outsider Art Research Collection of the University of Sydney (STOARC) and Editor-in-Chief of Elsewhere. The International Journal of Self-taught and Outsider Art. He was President of the European Outsider Art Association from 2011-2012.

Rhodes is among the world's leading experts in Australian and International Self-Taught and Outsider Art. He has curated numerous exhibitions of emerging and established self-taught artists and contributed numerous publications to this area. His effort to strengthen the culture of Outsider Art by promoting International cooperation between Outsider Art Organisations at any level, provide for best practice principles to challenge society to embrace diversity.

Among his major publications are: Raw Erotica: Sex, Lust and Desire in Outsider Art, Watford, 2013; Outsider Art: Spontaneous Alternatives, London, 2000; Primitivism and Modern Art, London, 1994.

Carole Tansella, Section Editor 